\title{
Faktor prediktor gangguan penglihatan berat dan kebutaan pada penderita diabetes di Daerah Istimewa Yogyakarta
}

\author{
Predictors of severe visual impairment and blindness among \\ diabetic patients in the Special Territory of Yogyakarta \\ Rimawati Aulia Insani Sadarang ${ }^{1}$, Hari Kusnanto ${ }^{1}$, M. Bayu Sasongko²
}

Dikirim: 7 Juli 2017 Diterbitkan: 1 Desember 2017

\section{Abstract}

Purpose: The purpose of this study was to identify any predictors of severe visual impairment and blindness among diabetic patients in Daerah Istimewa Yogyakarta. Methods: This research was a cross-sectional study by analyzing registry data from (JOGED.COM). Data included sociodemographic characteristics, diabetic status, health record, and eye diseases. The analysis was done using chi-square and simple logistic regression tests follow with semi-partial correlation, stratification tests and multilevel analysis. Results: 1093 data were included in this study. The prevalence of severe visual impairment was $12 \%$ and blindness was $6.5 \%$. Cataract, diabetic retinopathy and diabetes duration $>10$ years were statistically significant with severe visual impairment and blindness while glaucoma and hypertension only significant with severe visual impairment. The contribution of cataract in severe visual impairment $(4.73 \%)$ and blindness (3.11\%) was highest among eye diseases. There was modification effect of cataract to severe visual impairment and blindness by diabetes duration. Based on GEE, cataract, diabetic retinopathy and diabetes duration $>10$ years was the best model to predict the occurrence of severe visual impairment and blindness. Conclusions: Predictors of severe visual impairment and blindness among diabetic patients in Daerah Istimewa Yogyakarta were the cataract, diabetic retinopathy and diabetes duration $>10$ years. Modification effect of cataract by diabetes duration only was significant in a model to predict blindness.

Keywords: blindness; cataract; diabetic retinopathy; diabetes; visual impairment

\footnotetext{
${ }^{1}$ Departemen Biostatistik, Epidemiologi, dan Kesehatan Populasi, Fakultas Kedokteran, Universitas Gadjah Mada 


\section{PENDAHULUAN}

Gangguan penglihatan dan kebutaan merupakan masalah kesehatan yang tidak hanya mempengaruhi kualitas hidup penderita tetapi juga mempengaruhi tingkat produktivitas penderita. Sekitar 285 juta orang di seluruh dunia menderita gangguan penglihatan dan 14\% diantaranya mengalami kebutaan1.

Diabetes menjadi penyebab utama kebutaan pada penduduk berusia 20-74 tahun2. Risiko hilangnya kemampuan melihat pada penderita diabetes 25 kali lebih tinggi dibandingkan dengan bukan penderita diabetes3. Salah satu faktor yang berasosiasi dengan terjadinya gangguan penglihatan bahkan kebutaan pada penderita diabetes adalah durasi diabetes. Penderita dengan durasi diabetes $>10$ tahun berisiko 1,42 kali mengalami katarak ( $\mathrm{p}=0.035)$, berisiko 1,76 kali mengalami glaukoma $(\mathrm{p}=0.008)$ dan berisiko 2,94 kali mengalami retinopati diabetik $(\mathrm{p}<0.001) 4$.

Di Indonesia, angka prevalensi penyakit mata dan kebutaan khusus pada penderita diabetes cukup sulit untuk diidentifikasi. Secara umum, penyebab kebutaan terbanyak di Indonesia adalah katarak. Insiden katarak diestimasikan mencapai angka $0,1 \%$ per tahun. Penduduk Indonesia memiliki peluang untuk mengalami katarak 15 tahun lebih cepat dibandingkan dengan penduduk di daerah subtropis5.

Daerah Istimewa Yogyakarta (DIY) adalah provinsi dengan prevalensi diabetes yang terdiagnosis dokter tertinggi di Indonesia. Angka prevalensi diabetes di DIY adalah 2,6\%, mengalahkan angka prevalensi diabetes di Indonesia secara umum, yaitu 1,5\%6. Situasi ini mengarahkan pada sebuah asusmsi bahwa penderita diabetes di DIY telah mengalami gangguan penglihatan dan kebutaan akibat diabetes. Penelitian ini bertujuan untuk mengidentifikasi faktor prediktor gangguan penglihatan berat dan kebutaan pada penderita diabetes di Daerah Istimewa Yogyakarta.

\section{METODE}

Penelitian ini menggunakan desain cross-sectional study dan menggunakan data register Jogjakarta Eye Diabetic Study in the Community (JOGED.COM) tahun 2014 - 2016 sebanyak 1093 data yang terdiri dari karakteristik sosial demografi, status diabetes, riwayat kesehatan dan penyakit mata. Populasi penelitian pada JOGED.COM adalah penderita diabetes tipe 2 yang ada di DIY. Perekrutan subjek penelitian menggunakan kriteria inklusi, yaitu berdomisili di wilayah kerja puskesmas yang menjadi tempat pelaksanaan penelitian JOGED.COM dan harus didampingi oleh dokter kelurga atau perawat setempat bagi penderita diabetes dengan kondisi cacat fisik. Kriteria eksklusi yang diterapkan adalah menderita cacat intelektual7.

Gangguan penglihatan berat didefinisikan sebagai ketajaman penglihatan $<6 / 60-<3 / 60$ dan kebutaan sebagai ketajaman penglihatan $<3 / 608$. Data dianalisis menggunakan uji chi-square dan simple logistic regression. Uji semi partial correlation dilakukan untuk mengetahui kontribusi penyakit mata secara spesifik terhadap gangguan penglihatan berat dan kebutaan sementara uji Mantel-Haenzel untuk mengindentifikasi adanya potensi interaksi. Penentuan model prediktor terbaik menggunakan analisis multilevel dengan Generalized Estimation Equation (GEE).

Penelitian ini telah memperoleh izin penggunaan data sekunder dari Unit Penelitian dan Oftalmologi Komunitas Ilmu Kesehatan Mata Fakultas Kedokteran Universitas Gadjah Mada (FK UGM) dan persetujuan Komisi Etik FK UGM.

\section{HASIL}

\section{Karakteristik subjek penelitian}

Prevalensi gangguan penglihatan berat dan kebutaan pada penderita diabetes di Daerah Istimewa Yogyakarta adalah $12 \%$ dan 6,5\%. Kecenderungan gangguan penglihatan pada penderita diabetes mulai dialami memasuki umur 60 tahun (Tabel 1).

Penyakit mata, gangguan penglihatan berat dan kebutaan

Penyakit mata dengan prevalensi tertinggi pada penelitian ini adalah retinopati diabetik $(36,55 \%)$ dan terendah adalah glaukoma (1,37\%). Keempat penyakit mata secara statistik signifikan berhubungan dengan gangguan penglihatan berat dan kebutaan (Tabel 2).

Faktor prediktor gangguan penglihatan berat dan kebutaan

Katarak teridentifikasi sebagai penyakit mata dengan nilai asosiasi dan nilai kontribusi terbesar terhadap gangguan penglihatan berat dan kebutaan dibandingkan ketiga jenis penyakit mata lainnya (tabel 3). Selain penyakit mata, teridentifikasi pula faktor prediktor lain, seperti durasi diabetes $>10$ tahun, yang signifikan secara statistik terhadap gangguan penglihatan berat dan kebutaan pada penderita diabetes di Daerah Istimewa Yogyakarta (Tabel 4). 
Tabel 1.Karakteristik Penderita Diabetes di Daerah Istimewa Yogyakarta tahun 2014 - 2016

\begin{tabular}{|c|c|c|c|c|c|}
\hline \multirow[b]{2}{*}{ Karakteristik } & \multirow[b]{2}{*}{$\begin{array}{c}n \\
(1093)\end{array}$} & \multicolumn{4}{|c|}{ Gangguan Ketajaman Penglihatan } \\
\hline & & $\begin{array}{l}\text { Normal } \\
(n=418)\end{array}$ & $\begin{array}{l}\text { Sedang } \\
(n=490)\end{array}$ & $\begin{array}{c}\text { Berat } \\
(n=73)\end{array}$ & $\begin{array}{c}\text { Buta } \\
(n=112)\end{array}$ \\
\hline Umur (tahun) & $\begin{array}{c}59 \\
(16-88)^{*}\end{array}$ & $\begin{array}{c}56 \\
(16-80)^{*}\end{array}$ & $\begin{array}{c}59,9 \\
(9,68)\end{array}$ & $\begin{array}{c}61,1 \\
(8,15)\end{array}$ & $\begin{array}{c}62 \\
(10,22)\end{array}$ \\
\hline \multicolumn{6}{|l|}{ Jenis kelamin } \\
\hline Laki-laki & 341 & $136(39,88)$ & $150(43,99)$ & $26(7,62)$ & $29(8,50)$ \\
\hline Perempuan & 752 & $282(37,50)$ & $340(45,21)$ & $47(6,25)$ & $83(11,04)$ \\
\hline \multicolumn{6}{|l|}{ Status pernikahan } \\
\hline Tidak menikah & 14 & $6(42,86)$ & $4(28,57)$ & $0(0)$ & $4(28,57)$ \\
\hline Menikah & 907 & $363(40,02)$ & $399(43,99)$ & $61(6,73)$ & $84(9,26)$ \\
\hline Cerai & 14 & $5(35,71)$ & $6(42,86)$ & $2(14,29)$ & $1(7,14)$ \\
\hline Duda/ janda & 158 & $44(27,85)$ & $81(51,27)$ & $10(6,33)$ & $23(14,56)$ \\
\hline \multicolumn{6}{|l|}{ Tingkat pendidikan } \\
\hline Tidak sekolah & 111 & $30(27,03)$ & $53(47,57)$ & $8(7,21)$ & $20(18,20)$ \\
\hline SD & 323 & $105(32,51)$ & $158(48,92)$ & $27(8,36)$ & $33(10,22)$ \\
\hline SMP & 203 & $95(46,80)$ & $75(36,95)$ & $14(6,90)$ & $19(9,36)$ \\
\hline SMA & 300 & $128(42,67)$ & $132(44)$ & $15(5)$ & $25(8,33)$ \\
\hline S1 & 148 & $57(38,51)$ & $69(46,62)$ & $8(5,41)$ & $14(9,46)$ \\
\hline Pascasarjana & 8 & $3(37,50)$ & $3(37,50)$ & $1(12,50)$ & $1(12,50)$ \\
\hline \multicolumn{6}{|l|}{ Tipe Diabetes } \\
\hline Tipe 1 & 10 & $5(50)$ & $4(40)$ & $0(0)$ & $1(10)$ \\
\hline Tipe 2 & 1082 & $412(38,08)$ & $486(44,92)$ & $73(6,75)$ & $111(10,26)$ \\
\hline Gestasional & 1 & $1(100)$ & $0(0)$ & $0(0)$ & $0(0)$ \\
\hline \multicolumn{6}{|l|}{ Umur terdiagnosis } \\
\hline$<40$ tahun & 93 & $38(40,86)$ & $36(38,71)$ & $6(6,45)$ & $13(13,98)$ \\
\hline$\geq 40$ tahun & 1000 & $380(38)$ & $454(45,40)$ & $67(6,70)$ & $99(9,90)$ \\
\hline \multicolumn{6}{|l|}{ Durasi diabetes } \\
\hline$<10$ tahun & 842 & $344(40,86)$ & $376(44,66)$ & $47(5,58)$ & $75(8,91)$ \\
\hline$\geq 10$ tahun & 251 & $74(29,48)$ & $114(45,42)$ & $26(10,36)$ & $37(14,74)$ \\
\hline \multicolumn{6}{|l|}{$\overline{\text { Hipertensi }}$} \\
\hline $\mathrm{Ya}$ & 631 & $230(36,45)$ & $287(45,48)$ & $48(7,61)$ & $66(10,46)$ \\
\hline Tidak & 462 & $188(40,69)$ & $203(43,94)$ & $25(5,41)$ & $46(9,96)$ \\
\hline
\end{tabular}

Tabel 2. Hubungan penyakit mata terhadap gangguan penglihatan pada penderita diabetes

\begin{tabular}{|c|c|c|c|c|c|c|}
\hline \multirow{3}{*}{$\begin{array}{c}\text { Penyakit } \\
\text { Mata }\end{array}$} & \multirow{3}{*}{$\begin{array}{c}n \\
(2186)\end{array}$} & \multicolumn{4}{|c|}{$\begin{array}{c}\text { Gangguan Ketajaman } \\
\text { Penglihatan }\end{array}$} & \multirow{3}{*}{$\mathbf{P}$} \\
\hline & & Normal & $\begin{array}{c}\text { Sedan } \\
\mathrm{g}\end{array}$ & Berat & Buta & \\
\hline & & \multicolumn{4}{|c|}{$(n=1039) \stackrel{(n=882}{)^{2}}(n=123) \quad(n=142)$} & \\
\hline AMD & 149 & $\begin{array}{c}58 \\
(38,93)\end{array}$ & $\begin{array}{c}76 \\
(51,01)\end{array}$ & $5(3,36)$ & $10(6,71)$ & 0,037 \\
\hline Glaukoma & 30 & $7(23,33)$ & $\begin{array}{c}16 \\
(53,33)\end{array}$ & $5(16,67$ & $5(16,67)$ & 0,019 \\
\hline Katarak & 377 & $\begin{array}{c}78 \\
(20,69)\end{array}$ & $\begin{array}{c}195 \\
(51,72)\end{array}$ & $\begin{array}{c}44 \\
(11,67)\end{array}$ & $\begin{array}{c}60 \\
(15,92)\end{array}$ & $<0,001$ \\
\hline $\begin{array}{l}\text { Retinopati } \\
\text { diabetik }\end{array}$ & 799 & $\begin{array}{c}331 \\
(41,43)\end{array}$ & $\begin{array}{c}348 \\
(43,55)\end{array}$ & $50(6,2$ & $70(8,76)$ & $<0,001$ \\
\hline
\end{tabular}

Penderita diabetes yang mengalami katarak memiliki risiko lebih tinggi 3,89 kali mengalami gangguan penglihatan dan 3,98 kali mengalami kebutaan dibanding penderita diabetes yang tidak mengalami katarak, namun besar risiko tersebut mengalami penurunan setelah mempertimbangkan durasi diabetes. Teridentifikasi adanya modifikasi efek katarak terhadap gangguan penglihatan berat dan kebutaan berdasarkan durasi diabet
Tabel 3. Faktor prediktor gangguan penglihatan berat dan kebutaan berdasarkan penyakit mata

\begin{tabular}{|c|c|c|c|c|c|}
\hline \multirow{3}{*}{$\begin{array}{c}\text { Faktor } \\
\text { Prediktor }\end{array}$} & \multicolumn{4}{|c|}{ Gangguan Penglihatan Berat } & \multirow{3}{*}{$\begin{array}{c}\text { Semi } \\
\begin{array}{c}\text { Partial } \\
\text { Correlati } \\
\text { on }\end{array} \\
\mathbf{R}^{2}\end{array}$} \\
\hline & \multicolumn{2}{|c|}{ Mata kanan } & \multicolumn{2}{|c|}{ Mata kiri } & \\
\hline & $\mathbf{O P}$ & $95 \% \mathrm{CI}$ & OP & $95 \% \mathrm{CI}$ & \\
\hline$\overline{\text { Katarak }}$ & $205 *$ & בעם & 20 5* & $\frac{5}{01}$ & ח \\
\hline Katarak & 3,85 & $2,54-5,80$ & 3,95 & $\begin{array}{l}2,01-5,95 \\
020\end{array}$ & $0,04 / 3$ \\
\hline Glaukoma & 1,97 & $0,35-7,59$ & 2,49 & $0,57-8,38$ & $0,0053^{*}$ \\
\hline $\begin{array}{l}\text { Retinopati } \\
\text { diabetik }\end{array}$ & $1,62^{*}$ & $1,10-2,36$ & 1,42 & $0,96-2,08$ & 0,0012 \\
\hline \multirow[t]{4}{*}{ AMD } & 0,72 & $0,27-1,62$ & 0,88 & $0,36-1,90$ & 0,0000 \\
\hline & \multicolumn{4}{|c|}{ Buta } & Semi \\
\hline & \multicolumn{2}{|c|}{ Mata kanan } & \multicolumn{2}{|c|}{ Mata kiri } & Correlati \\
\hline & $\overline{\text { OR }}$ & $95 \% \mathrm{CI}$ & OR & $95 \% \mathrm{CI}$ & $\overline{\mathbf{R}^{2}}$ \\
\hline Katarak & $4,16^{*}$ & $2,42-7,04$ & $3,83^{*}$ & $2,23-6,48$ & $0,0311^{*}$ \\
\hline $\begin{array}{l}\text { Retinopati } \\
\text { diabetik }\end{array}$ & $2,65^{*}$ & $1,58-4,49$ & 1,16 & $0,68-1,94$ & $0,0057^{*}$ \\
\hline Glaukoma & 2,44 & $\begin{array}{l}0,26- \\
11,28\end{array}$ & $3,42^{*}$ & $\begin{array}{l}0,61- \\
12,86\end{array}$ & $0,0019 *$ \\
\hline AMD & 1,03 & $0,31-2,64$ & 1,04 & $0,32-2,69$ & 0,0002 \\
\hline
\end{tabular}


Tabel 4. Faktor Prediktor Gangguan Penglihatan Berat dan Kebutaan berdasarkan Karakteristik Individu

\begin{tabular}{|c|c|c|c|c|}
\hline \multirow{2}{*}{$\begin{array}{l}\text { Faktor } \\
\text { Prediktor }\end{array}$} & \multicolumn{2}{|c|}{$\begin{array}{c}\text { Gangguan } \\
\text { penglihatan berat }\end{array}$} & \multicolumn{2}{|c|}{ Buta } \\
\hline & OR & $95 \% \mathrm{CI}$ & OR & $95 \% \mathrm{CI}$ \\
\hline \multicolumn{5}{|l|}{ Jenis kelamin } \\
\hline Laki-laki & 1 & & 1 & \\
\hline Perempuan & 1,14 & $0,86-1,52$ & 1,47 & $0,99-2,19$ \\
\hline \multicolumn{5}{|l|}{$\begin{array}{l}\text { Status } \\
\text { pernikahan }\end{array}$} \\
\hline Tidak & 1 & & 1 & \\
\hline menikah & $0,32 *$ & $0,14-0,74$ & $0,23^{*}$ & $0,09-0,57$ \\
\hline Menikah & 0,41 & $0,11-1,59$ & 0,13 & $0,01-1,21$ \\
\hline Cerai & 0,42 & $0,17-1,02$ & $0,37^{*}$ & $0,14-0,99$ \\
\hline \multicolumn{5}{|l|}{ Duda/ janda } \\
\hline \multicolumn{5}{|l|}{ Tingkat } \\
\hline pendidikan & 1 & & 1 & \\
\hline luak sekolan & $0,65^{*}$ & $0,44-0,98$ & $0,57^{*}$ & $0,34-0,97$ \\
\hline $\begin{array}{l}\text { SD } \\
\text { SMP }\end{array}$ & $0,53^{*}$ & $0,34-0,83$ & $0,54^{*}$ & $0,30-0,97$ \\
\hline $\begin{array}{l}\text { SIMP } \\
\text { SMA }\end{array}$ & $0,39 *$ & $0,25-0,61$ & $0,42^{*}$ & $0,24-0,74$ \\
\hline SMA & $0,52^{*}$ & $0,32-0,85$ & 0,63 & $0,34-1,16$ \\
\hline $\begin{array}{l}\text { S1 } \\
\text { Pasca sariana }\end{array}$ & 0,96 & $0,26-3,52$ & 0,55 & $0,07-4,35$ \\
\hline \multicolumn{5}{|l|}{ Jenis } \\
\hline Pekerjaan & 1 & & 1 & \\
\hline Tidak bekerja & 0,86 & $0,53-1,41$ & 1,29 & $0,72-2,30$ \\
\hline PNS & $0,63^{*}$ & $0,44-0,91$ & $0,53^{*}$ & $0,31-0,91$ \\
\hline Swasta & $0,59 *$ & $0,41-0,85$ & 0,69 & $0,43-1,10$ \\
\hline $\begin{array}{l}\text { Wiraswasta } \\
\text { Pensiunan }\end{array}$ & $0,52^{*}$ & $0,34-0,79$ & 0,68 & $0,40-1,16$ \\
\hline \multicolumn{5}{|l|}{ Tipe diabetes } \\
\hline Gestasional & 1 & & 1 & \\
\hline Tipe 1 & 0,80 & $0,18-3,48$ & 1,60 & $0,37-6,99$ \\
\hline Tipe 2 & 1 & & 1 & \\
\hline \multicolumn{5}{|l|}{ Umur } \\
\hline diabetes & 1 & & 1 & \\
\hline$\geq 40$ tahun & 1,32 & $0,86-2,01$ & 1,39 & $0,81-2,41$ \\
\hline$<40$ tahun & & & & \\
\hline \multicolumn{5}{|l|}{ Durasi } \\
\hline diabetes & 1 & & 1 & \\
\hline$<10$ tahun & $1,77^{*}$ & $1,34-2,34$ & $1,67^{*}$ & $1,15-2,41$ \\
\hline$\geq 10$ tahun & & & & \\
\hline Hipertensi & 1 & & 1 & \\
\hline $\begin{array}{l}\text { Tidak } \\
\text { Ya }\end{array}$ & $1,36^{*}$ & $1,04-1,77$ & 1,03 & $0,73-1,46$ \\
\hline
\end{tabular}

Faktor prediktor terhadap gangguan penglihatan berat dan kebutaan pada penderita diabetes di Daerah Istimewa Yogyakarta adalah katarak, retinopati diabetik dan durasi diabetes $>10$ tahun. Nilai asosiasi faktor prediktor tersebut dideskripsikan melalui model 2 untuk gangguan penglihatan berat dan model 1 untuk kebutaan (Tabel 5).

\section{BAHASAN}

Prevalensi gangguan penglihatan berat dan kebutaan pada penelitian ini teridentifikasi lebih tinggi jika dibandingkan dengan prevalensi kebutaan penderita diabetes di daerah perkotaan Kumba, Kamerun9 dan di wilayah Mopani, Afrika Selatan10. Namun, prevalensi kebutaan pada penderita diabetes di Yamen teridentifikasi lebih tinggi dibandingkan penelitian ini (11).
Hubungan antara karakteristik penderita diabetes dengan terjadinya gangguan penglihatan dan kebutaan telah teridentifikasi pada penelitian sebelumnya $(4,12,13)$ demikian pula dengan kontribusi penyakit mata pada penderita diabetes $(14,15)$. Sebuah studi kohort pada penderita yang baru terdiagnosis diabetes secara klinis menunjukkan penderita diabetes yang mengalami penurunan penglihatan 76\% menderita katarak dan 58\% menderita retinopati diabetik semantara AMD teridentifikasi berkontribusi pada $68,75 \%$ kebutaan pada penderita diabetes setelah follow-up selama enam tahun (16).

Pada penelitian ini, penyakit mata pada penderita diabetes teridentifikasi memiliki hubungan dengan terjadinya gangguan penglihatan berat dan kebutaan. Katarak adalah penyakit mata dengan nilai asosiasi dan kontribusi terbesar terhadap gangguan penglihatan berat dan kebutaan dibanding AMD, glaukoma dan retinopati diabetik (Tabel 3). Hasil penelitian ini sejalan dengan penelitian sebelumnya $(10,11)$.

Katarak adalah kondisi dipengaruhi oleh penambahan umur, namun pada kondisi diabetes, pembentukan katarak lebih cepat dari umur pembentukan katarak pada umumnya yang disebabkan oleh reaksi biokimia antara partikel enzim dan glaukosa (17). Risiko katarak pada penderita diabetes teridentifikasi mengalami peningkatan 2-5 kali dibanding bukan penderita diabetes. Kondisi ini disebabkan oleh peningkatan jumlah sorbitol yang terbentuk dari kadar glikemik yang tinggi pada penderita diabetes. Risiko katarak teridentifikasi dapat lebih tinggi 15 - 25 kali pada penderita diabetes yang terdiagnosis pada umur $<40$ tahun (18).

Rata-rata penderita diabetes pada penelitian ini berumur 59 tahun (16-88) dan telah berpotensi mangalami katarak yang disebabkan oleh faktor penambahan umur. Asosiasi umur dan pembentukan katarak pada penelitian ini didukung oleh perhitungan statistik yang menunjukkan peningkatan risiko katarak setiap penambahan umur 1 tahun.

Potensi kontribusi katarak terhadap gangguan penglihatan berat dan kebutaan juga teridentifikasi pasca operasi katarak. Operasi katarak dapat berimplikasi pada peningkatan kerusakan retina, seperti pembentukan pembuluh darah yang tidak normal, dan risiko perubahan makula, seperti pembengkakan makula pada mata yang telah dioperasi (19). Kontribusi retinopati diabetik terhadap gangguan penglihatan berat dan kebutaan pada penelitian ini teridenfitikasi $<1 \%$. Nilai kontribusi ini lebih rendah dibandingkan nilai kontribusi retinopati diabetik 
terhadap kebutaan pada populasi umum berkisar 5-15\% dan pada penderita diabetes tipe 2 berkisar 30-50 yang pernah terlaporkan16. Kontribusi retinopati diabetik terhadap gangguan penglihatan berat dan kebutaan didukung oleh beberapa faktor, seperti hipertensi dan kontrol glikemik yang buruk (10) dan dapat bermanifestasi melalui mikroaneurisme, perdarahan intraretina, hard exudates, cotton-wool spot, dan abnormalitas mikrovaskuler intraretina (20).

Durasi diabetes $>10$ tahun teridentifikasi meningkatan risiko gangguan penglihatan berat dan kebutaan secara signifikan (Tabel 4). Penelitian sebelumnya menunjukkan seluruh penderita diabetes yang mengalami kebutaan bilateral telah menderita diabetes $>10$ tahun (21). Secara spesifik, durasi diabetes $>10$ tahun berkontribusi terhadap penyakit mata, seperti glaukoma, katarak dan retinopati diabetik signifikan secara statistik (4). Penderita diabetes dengan katarak dan memiliki durasi diabetes <10 tahun teridentifikasi berisiko gangguan penglihatan berat lebih tinggi dibandingkan penderita diabetes dengan katarak namun durasi diabetes >10 tahun, demikian pula dengan risiko mengalami kebutaan. Risiko kebutaan pada penderita diabetes dengan katarak dan durasi diabetes <10 tahun lebih tinggi dibanding penderita diabetes dengan katarak dan durasi diabetes $>10$ tahun.

Modifikasi efek katarak terhadap gangguan penglihatan berat dan kebutaan oleh durasi diabetes dapat dijelaskan oleh kondisi berikut. Rata-rata penderita diabetes pada penelitian ini berumur 59 tahun (16-88) dan telah berpotensi mengalami katarak yang disebabkan oleh faktor penambahan umur. Asosiasi umur dan pembentukan katarak pada penelitian ini didukung oleh perhitungan statistik yang secara signifikan menunjukkan peningkatan risiko katarak setiap penambahan umur 1 tahun. Disamping itu, proporsi penderita diabetes yang terdiagnosis pada umur $>40$ dan durasi diabetes < 10 tahun lebih tinggi dibanding penderita yang terdiagnosis diabetes pada umur < 40 tahun dan durasi diabetes >10 tahun sehingga potensi pembentukan katarak telah terjadi sebelum terdiagnosis diabetes dan atau perbentukan katarak diabetes berlangsung cepat, <10 tahun sejak terdiagnosis diabetes, yang merupakan kombinasi faktor umur dan diabetes.

\section{Keterbatasan Penelitian}

Kelebihan penelitian ini terletak pada jumlah sampel yang besar dengan pengambilan subjek penelitian secara stratified random sampling di beberapa puskesmas yang ada di Daerah Istimewa
Yogyakarta sehingga hasil penelitian dapat digeneralisir kepada seluruh penderita diabetes yang ada di Daerah Istimewa Yogyakarta. Selain itu, pemeriksaan ketajaman penglihatan dan diagnosis penyakit mata dilakukan melalui pemeriksaan langsung oleh residen senior bagian mata Fakultas Kedokteran Universitas Gadjah Mada yang terlatih sehingga data yang dihasilkan valid.

Keterbatasan penelitian terletak pada penggunaan desain cross-sectional sehingga hubungan kausal antara variabel bebas dan variabel terikat tidak dapat diinterpretasikan. Selain itu, data terkait kadar glikemik dan riwayat melakukan operasi katarak tidak tersedia sehingga pada penelitian ini tidak dapat dilakukan identifikasi potensi kontribusi penyakit mata terhadap gangguan penglihatan berat dan kebutaan dari segi kualitas kontrol glikemik dan riwayat melakukan operasi katarak.

\section{SIMPULAN}

Pada penderita diabetes di Daerah Istimewa Yogyakarta teridentifikasi prevalensi retinopati diabetik (36,55\%), katarak (17,24\%), AMD (6,81\%) dan glaukoma (1,37\%). Keempat penyakit mata tersebut secara statistik signifikan berhubungan dengan gangguan penglihatan berat dan kebutaan. Katarak berkontribusi $4,73 \%$ terhadap gangguan penglihatan berat dan 3,11\% terhadap kabutaan, sementara retinopati diabetik, glaukoma dan AMD berkontribusi $<1 \%$ baik terhadap gangguan penglihatan maupun kebutaan penderita diabetes. Faktor prediktor gangguan penglihatan berat dan kebutaan pada penderita diabetes di Daerah Istimewa Yogyakarta adalah katarak, retinopati diabetik dan durasi diabetes $>10$ tahun.

\section{Abstrak}

Tujuan: Penelitian ini bertujuan untuk mengetahui faktor prediktor terjadinya gangguan penglihatan berat dan kebutaan pada penderita diabetes di Daerah Istimewa Yogyakarta. Metode: Penelitian ini menggunakan desain cross-sectional study dan memanfaatkan data register Jogjakarta Eye Diabetic Study in the Community (JOGED.COM). Data yang dianalisis meliputi karakteristik sosial demografi, status diabetes, riwayat kesehatan dan penyakit mata. Analisis data menggunakan uji chi-square dan simple logistic regression dengan analisa tambahan estimasi korelasi semi parsial, stratifikasi dan 
multilevel menggunakan Generelized Estimation Equation (GEE). Hasil: Terdapat 1093 data register penderita diabetes dalam penelitian ini. Teridentifikasi prevalensi gangguan penglihatan berat dan kebutaan adalah $12 \%$ dan 6,5\%. Pada analisis, katarak, retinopati diabetik dan durasi diabetes $>10$ tahun signifikan berhubungan baik terhadap gangguan penglihatan berat maupun kebutaan, sementara glaukoma dan hipertensi hanya berhubungan dengan gangguan penglihatan berat. Katarak adalah penyakit mata dengan kontribusi terbesar baik terhadap gangguan penglihatan berat (4,73\%) maupun kebutaan (3,11\%). Terdapat modifikasi efek katarak terhadap gangguan penglihatan berat dan kebutaan berdasarkan durasi diabetes yang signifikan secara statistik. Hasil analisis GEE menunjukkan katarak, retinopati diabetik dan durasi diabetes $>10$ tahun adalah model prediktor terbaik terhadap gangguan penglihatan berat dan kebutaan. Kesimpulan: Faktor prediktor gangguan penglihatan berat dan kebutaan pada penderita diabetes di Daerah Istimewa Yogyakarta adalah katarak, retinopati diabetik dan durasi diabetes $>10$ tahun. Modifikasi efek durasi diabetes $>$ 10 tahun terhadap kontribusi katarak hanya signifikan pada outcome kebutaan.

Kata kunci: diabetes; gangguan penglihatan; katarak; kebutaan; retinopati diabetik

Tabel 5. Analisis multilevel generalized estimation equation katarak, retinopati diabetik dan Glaukoma

\begin{tabular}{|c|c|c|c|c|}
\hline \multirow{2}{*}{ Model } & \multicolumn{4}{|c|}{ Gangguan Penglihatan Berat } \\
\hline & OR & $\mathbf{P}>[\mathrm{z}]$ & $95 \% \mathrm{CI}$ & QIC \\
\hline \multicolumn{5}{|l|}{$\overline{\text { Model 1 }}$} \\
\hline Katarak & 3,89 & $<0,001$ & $1,02-1,71$ & \multirow{3}{*}{1527.528} \\
\hline Retinopati Diabetik & 1,43 & 0,025 & $0,04-0,67$ & \\
\hline Constanta & 0,08 & $<0,001$ & $-2,70-2,24$ & \\
\hline \multicolumn{5}{|l|}{ Model 2} \\
\hline Retinopati diabetik & 1,38 & 0,053 & $-0,00-0,64$ & \multirow{4}{*}{1523.544} \\
\hline Katarak & 3,74 & $<0,001$ & $0,97-1,67$ & \\
\hline Durasi diabetes $\geq 10$ & 1,52 & 0,023 & $0,05-0,79$ & \\
\hline $\begin{array}{l}\text { tahun } \\
\text { Constanta }\end{array}$ & 0,78 & $<0,001$ & $-2,79--2,32$ & \\
\hline \multicolumn{5}{|l|}{ Model 3} \\
\hline Glaukoma & 2,34 & 0,136 & $-2,67-1,97$ & \multirow{4}{*}{1528.602} \\
\hline Retinopati diabetik & 1,42 & 0,029 & $0,03-0,67$ & \\
\hline Katarak & 3,89 & $<0,001$ & $1,01-1,70$ & \\
\hline Constanta & 0,08 & $<0,001$ & $-2,71--2,24$ & \\
\hline \multirow{2}{*}{ Model } & \multicolumn{4}{|c|}{ Kebutaan } \\
\hline & OR & $\mathbf{P}>[\mathrm{z}]$ & 95\%CI & QIC \\
\hline \multicolumn{5}{|l|}{$\overline{\text { Model } 1}$} \\
\hline Katarak & 5,58 & $<0,001$ & $1,20-2,23$ & \multirow{5}{*}{988.433} \\
\hline Retinopati diabetik & 1,75 & 0,007 & $0,15-0,97$ & \\
\hline Durasi diabtes $\geq 10$ tahun & 2,07 & 0,008 & $0,19-1,27$ & \\
\hline $\begin{array}{l}\text { Katarak*durasi diabetes } \\
>10 \text { tahun }\end{array}$ & 0,34 & 0,018 & $-1,94-0,18$ & \\
\hline Constanta & 0,03 & $<0,001$ & $-3,86--3,14$ & \\
\hline \multicolumn{5}{|l|}{ Model 2} \\
\hline Retinopati diabetik & 1,78 & 0,004 & $0,18-0,98$ & \multirow{3}{*}{993.747} \\
\hline Katarak & 4,09 & $<0,001$ & $0,99-1,83$ & \\
\hline Constanta & 0,03 & $<0,001$ & $-3,62--2,98$ & \\
\hline \multicolumn{5}{|l|}{ Model 3} \\
\hline Glaukoma & 2,88 & 0,137 & $0,34-2,46$ & \multirow{4}{*}{994.624} \\
\hline Retinopati diabetik & 1,78 & 0,005 & $0,17-0,98$ & \\
\hline Katarak & 4,05 & $<0,001$ & $0,98-1,82$ & \\
\hline Constanta & 0,03 & $<0,001$ & $-3,64--3,00$ & \\
\hline
\end{tabular}




\section{PUSTAKA}

1. World Health Organization. Global Data on Visual Impairments 2010. Geneva: WHO Press; 2012.

2. Centers for Disease Control and Prevention. National Diabetes Fact Sheet, 2011. Atlanta: U. S. Department of Health and Human Services, CDC; 2011.

3. International Diabetic Federation Europe. Diabetes \& Blindness due to DME. Diakses dari: www.idf.org [Tanggal 10 Desember 2016].

4. Jingi, A.M., Nansseu, J.R.N., Noubiap, J.J.N., Bilong, Y., Ellong, A. \& Mvogo, C.E. Diabetes and Visual Impairment in Sub-Sahara Africa: Evidence from Cameroon. Journal of Diabetes \& Metabolic Disorders. 2015; 14(21): 1-8. Diakses dari: $\quad$ http://doi.10.1186/s40200-015-0151-4. [Tanggal 17 Desember 2016].

5. Kementerian Kesehatan RI. Situasi Gangguan Penglihatan dan Kebutaan. Jakarta Selatan: Pusat Data dan Informasi Kementerian Kesehatan RI; 2014.

6. Kementerian Kesehatan RI. Infodatin Situasi dan Analisis Diabetes. Jakarta Selatan: Pusat Data dan Informasi Kementerian Kesehatan RI; 2014.

7. Sasongko, M., Agni, A., Wardhana, F., Kotha, S., Gupta, P., Widayanti, T., Supanji, S., Widyaputri, F., Widyaningrum, R., Wong, T., Kawasaki, R., Wang, J. \& Prawiroranu, S. Rational and Methodology for a Community-Based Study of Diabetic Retinopathy among Indonesian Population with Type 2 Diabetes Mellitus: the Jogjakarta Eye Diabetic Study in the Community (JOGED.COM). Ophthalmic Epidemiology. 2016. Diakses dari: www.mc.manuscriptcentral.com [Tanggal 6 Desember 2016].

8. World Health Organization. Global Initiative for the Elimination of Avoidable Blindness: Action Plan 2006-2011. Geneva: WHO Press; 2007.

9. Ayukotang, E.N., Kumah, D.B. \& Mohammed, A.K. Prevalence of Visual Impairment among Diabetic Patients in the Kumba Urban Area, Cameroon. International Journal of Innovation and Applied Studies. 2016;15(4): 872-876. Diakses dari: www.ijias.issr-journal.org. [Tanggal 17 Desember 2016].

10. Mabaso, R.G. \& Oduntan, O.A. Prevalence and Cause of Visual Impairment and Blindness among Adults with Diabetes Mellitus Aged 40 years and Older Receiving Treatment at Government Health Facilities in the Mopani District, South Africa. The South African Optometrist. 2014;73 (1): 8-15. Diakses dari: www.avehjournal.org [Tanggal 10 Desember 2016].

11. Al-Akily, S.A., Bamashmus, M.A. \& Gunaid, A.A. Cause of Visual Impairment and Blindness among Yemenis with Diabetes: a Hospital-Based Study. Eastern Mediterranean Health Journal. 2011;17(11): 831-837. Diakses dari: www.icoph.org [Tanggal 17 Desember 2016].

12. Seba, E.G., Arunga, S., Bwonya, B.D. \& Twinamasiko, A. Prevalence, Risk Factors and Causes of Visual Impairment in Patients with Diabetes at Mbarara Regional Referral Hospital, South Western Uganda; A Hospital Based Study. Journal of Ophthalmology of Eastren Central and Southern Africa. 2015: 9-13. Diakses dari: Journal of ophtalmology of eastern central southern africa [Tanggal 2 Maret 2017].

13. Rani, P.K., Raman, R.., Gella, L., Kulothngan, V. \& Sharma, T. Prevalence of Visual Impairment and Associated Risk Factors in Subject with Type II Diabetes Mellitus: Sankara Nethralaya Diabetic Retinopathy Epidemiology and Molecular Genetics Study (SN-DREAM, Report 16). Middle East African Journal of Ophthalmology. 2012;19(1): 129-134. Diakses dari: http://doi: 10.4103/0974-9233.92129. [Tanggal 17 Desember 2016].

14. Moise M,M. \& Benjamin, L.M. Causes of Visual Disability among Central Africans with Diabetes Mellitus. African Health Science. 2012;12(2): 193-197. Diakses dari: http://dx.doi.org/10.4314/ahs.v12i2.18. [Tanggal 2 Maret 2017].

15. Kahloun, R., Jelliti, B., Zaouali, S., Attia, S., Yahia, S.B., Resnikoff, S. \& Khairallah, M. Prevalence and Cause of Visual Impairment in Diabetic Patients in Tunisia, North Africa. Eye. 2014;28: 986-991. Diakses dari: http://doi:10.1038/eye.2014.131. [Tanggal 17 Desember 2016].

16. De Fine Olivarius, N., Siersma, V., Almind, G.J. \& Nielsen, N.V. Prevalence and Progression of Visual Impairment in Patient Newly Diagnosed with Clinical Type 2 Diabetes: a 6 Year Follow Up Study. BMC Public Health. 2011;11(80): 1-13. Diakses dari: bmcpublichealth.biomedcentral [Tanggal 5 Desember 2016].

17. Wei, L.S. The Link between Diabetes and Eyesight. Diakses dari: www.drleoeyespecialist.com [Tanggal $28 \mathrm{Mei}$ 2017]

18. Lathika, V.K., \& Ajith, T.A. Association of Grade of Cataract with Duration of Diabetes, Age and Gender in Patients with Type II Diabetes Mellitus. International Journal of Advance in Medicine. 2016;3(2): 304-308. Diakses dari: www.ijmedicine.com. [Tanggal 11 Desember 2016].

19. Pollreisz, A. \& Erfurth, U.S. Diabetic Cataract Pathogenesis, Epidemiology and Treatment. Journal of Ophthalmology. 2011; 1-8. Diakses dari:http://doi.10.1155/2010/608751. [Tanggal 21 Februari 2017].

20. American Academy of Ophthalmology Retina/ Vitreous Panel. Preferred Prectice Pattern Diabetic Retinopathy, San Francisco: American Opthtalmology; 2016

21. Askira, B.H. \& Mubi, B.M. Blindness in Patients with Diabetes Mellitus Attending a Diabetes Clinic at the University of Maiduguri Teaching Hospital, Maiduguri. The Internet Journal of Ophthalmology and Visual Science. 2012;9(1): 1-5. Diakses dari: print.ispub.com. [Tanggal 8 Maret 2017].

22. Javadi, M.A. \& Ghanavati, S.Z. Cataract in Diabetic Patients: A Review Article. Journal of Ophthalmic and Vision Research. 2008;3(1): 52-65. Diakses dari: www.ncbi.nlm.nih.gov [Tanggal 27 Mei 2017]. 
Berita Kedokteran Masyarakat, Volume 33 No. 12 Tahun 2017 